\title{
Synthesis of Sulfonamide Derivatives of Carboranyl Porphyrins Based on 5-(4-Aminophenyl)-10,15,20-triphenylporphyrin and Mercapto
}

\section{Carboranes}

\author{
Valentina A. Ol'shevskaya ${ }_{1}{ }^{@}$ Viktoriya M. Alpatova, ${ }^{\mathrm{b}}$ Nadejda V. Konovalova, ${ }^{\mathrm{b}}$ \\ Elena G. Kononova, ${ }^{a}$ Yurii A. Borisov, ${ }^{a}$ Evgeny G. Rys, ${ }^{a}$ Elena S. Kolotova, ${ }^{c}$ \\ and Aleksander A. Shtilc
}

\author{
${ }^{a}$ A.N. Nesmeyanov Institute of Organoelement Compounds, Russian Academy of Sciences, 119991 Moscow, Russian \\ Federation \\ ${ }^{\mathrm{b}}$ Moscow Technological University, M.V. Lomonosov Institute of Fine Chemical Technologies, 119571 Moscow, Russian \\ Federation \\ 'N.N. Blokhin National Medical Center of Oncology, 115478 Moscow, Russian Federation \\ @Corresponding authorE-mail: olshevsk@ineos.ac.ru
}

\begin{abstract}
New carboranyl substituted sulfonamide porphyrins were synthesized in good yields by the reaction of amino group of 5-(p-aminophenyl)-10,15,20-triphenylporphyrin with carboranylsulfonyl chlorides prepared in situ by oxidative chlorination of corresponding mercapto carborane with trichloroisocyanuric acid in $\mathrm{MeCN}-\mathrm{H}_{2} \mathrm{O}$ system. The reactions were carried out under mild conditions. The structure of all compounds obtained was confirmed by means of electronic, $I R,{ }^{1} \mathrm{H}$ and ${ }^{11} B$ NMR spectroscopy and mass spectrometry. Quantum-chemical studies by DFT calculations were carried out for synthesized porphyrin derivatives.
\end{abstract}

Keywords: Porphyrins, metal complexes, carboranes, sulfonamide derivatives, DFT calculations.

\section{Синтез сульфонамидных производных карборанилпорфиринов на основе 5-(4-аминофенил)-10,15,20-трифенилпорфирина и меркаптокарборанов}

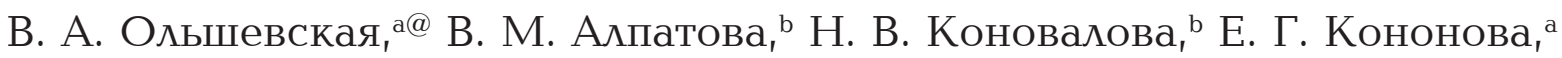 \\ Ю. А. Борисов, ${ }^{a}$ Е. Г. Рыс, ${ }^{a}$ Е. С. Колотова, ${ }^{\text {c }}$ А. А. Штиль ${ }^{\mathrm{c}}$ \\ ${ }^{a}$ Институт элементоорганических соединений им. А.Н. Несмеянова Российской академии наук, 119991 Москва, \\ Российская Федераиия \\ ${ }^{\mathrm{b}}$ Московский технологический университет, Институт тонких химических технологий им. М.В. Ломоносова, \\ 119571 Москва, Российская Федерация \\ 'Российский онкологический научный цеентр им. Н.Н. Блохина РАМН, 115478 Москва, Российская Федерация \\ @E-mail: olshevsk@ineos.ac.ru
}

\begin{abstract}
Осуществлен синтез новых сульфонамидных карборанилзамещченных порфиринов реакцией аминогруппь 5-(n-аминофенил)-10,15,20-трифенилпорфирина с карборанилсульфонилхлоридами. Последние были получены in situ окислительным хлорированием соответствующцих меркаптокарборанов трихлоризоциануровой кислотой.
\end{abstract}

Ключевые слова: Порфирины, металлокомплексы, карбораны, сульфонамидные производные, теория функционала плотности. 


\section{Introduction}

Porphyrins and their analogues are a class of chemically and biologically important compounds that have found a variety of applications in different fields such as catalysis, ${ }^{[1-3]}$ non-linear optics, ${ }^{[4]}$ materials, ${ }^{[5]}$ polymer synthesis ${ }^{[6]}$ and energy conversions. ${ }^{[7,8]}$ These macrocyclic compounds play also essential roles in biological systems in such processes as electron transfer, dioxygen transport, ${ }^{\left[{ }^{[]}\right.}$substrate transformations ${ }^{[10]}$ and photosynthesis. ${ }^{[1]]}$ Porphyrins have been extensively studied as potential photosensitizers in photodynamic therapy (PDT) ${ }^{[12,13]}$ exhibiting characteristics desirable for drug preparations including chemical purity, high quantum yield of singlet oxygen production, significant absorption at longer wavelengths, preferential tumor location, minimal dark toxicity, stability and the ability to dissolve in injectable solvent systems. The structure of these compounds allows for a variety of modifications of their molecules along the periphery of macrocycles in order to optimize their antitumor characteristics. The observed preferential uptake of porphyrin macrocycles in tumors and their efficient use in PDT have led to their investigation as boron delivery agents for boron neutron capture therapy (BNCT) ${ }^{[14,15]}$ Conjugates of porphyrins with carboranes are potential agents for use in PDT and BNCT. To continue our ongoing efforts on porphyrin functionalization, ${ }^{[16]}$ we present herein the synthesis of sulphonamide substituted boronated porphyrins based on reactions of 5-(4-aminophenyl)-10,15,20-triphenylporphyrin with mercapto carboranes. The sulfonamide functional groups can be found in a variety of drugs which show broad spectrum of pharmacological activity such as antitumor, ${ }^{[17,18]}$ anti$\mathrm{HIV},{ }^{[19]}$ antitubercular, ${ }^{[20]}$ antimicrobial, ${ }^{[21]}$ antileukemic, ${ }^{[22]}$ anticonvulsant and analgesic. ${ }^{[23]}$ In recent years sulfonamide substituted molecules have been investigated as inhibitors of carbonic anhydrase, ${ }^{[24]}$ carboxypeptidase A, ${ }^{[25]} \mathrm{HIV}-1$ integrase, ${ }^{[26]} \mathrm{HIV}-1$ protease, ${ }^{[27]}$ and as agonists of androgen receptor, ${ }^{[28]}$ and $\beta 3$-andrenergic receptor. ${ }^{[29]}$ By considering the anticancer significance of porphyrins and dependence of the biological properties of porphyrins on their peripheric substituents it was contemplated to synthesize new porphyrin structures combining porphyrin macrocycle, carborane and sulfonamide moiety within one molecule.

\section{Experimental}

All reactions were performed in an atmosphere of dry argon. All solvents were dried according to the standard protocols. ${ }^{1} \mathrm{H}$ and ${ }^{11} \mathrm{~B}$ NMR spectra were recorded on a Bruker Avance- 400 spectrometer operating at $400.13 \mathrm{MHz}$ for ${ }^{1} \mathrm{H} \mathrm{NMR}$ and $128.28 \mathrm{MHz}$ for ${ }^{11} \mathrm{~B}$ NMR. Chemical shifts $(\delta)$ were referenced to the residual solvent peak $\left(\mathrm{CDCl}_{3}, 1 \mathrm{H}: 7.26 \mathrm{ppm}\right)$ for ${ }^{1} \mathrm{H}$ and external $\mathrm{BF}_{3} \cdot \mathrm{OEt}_{2}$ for ${ }^{11} \mathrm{~B}$. IR spectra were recorded on a Bruker FTIR spectrometer Tensor 37 in $\mathrm{KBr}$ tablets. Merck silica gel L 0.040-0.080 mesh was used for column chromatography. The identities of new compounds were verified by TLC on Sorbfil and Kieselgel 60 F254 (Merck) plates. The UV-Vis spectra were measured on a spectrophotometer Carl Zeis Specord M 40 in $\mathrm{CH}_{2} \mathrm{Cl}_{2}$. The mass spectra were obtained using VISION 2000 (MALDI) mass spectrometer, the most intense peaks were given for each compound.

General procedure of synthesis of carboranylporphyrins 5-7. To a corresponding thiol $\mathbf{2 , 3}$ or 4 (14 mg, $0.08 \mathrm{mmol})$ in $\mathrm{MeCN}-\mathrm{H}_{2} \mathrm{O}$ mixture $(4.0 \mathrm{ml}, 1: 1)$ TCCA $(19.5 \mathrm{mg}, 0.08 \mathrm{mmol})$ was added at $4{ }^{\circ} \mathrm{C}$. The reaction was stirred for $15-20$ min under argon to yield desired carboranylsulfonyl chlorides $\mathbf{8 , 9}$ or $\mathbf{1 0}$. The completion of the reactions was confirmed by TLC (heptane- $\left.\mathrm{CH}_{2} \mathrm{Cl}_{2}, 1: 1\right)$. The prepared carboranylsulfonyl chloride $\mathbf{8 , 9}$ or $\mathbf{1 0}$ was added to a mixture of porphyrin $1(40 \mathrm{mg}, 0.06 \mathrm{mmol})$ and $\mathrm{NaOAc}(26.2 \mathrm{mg}, 0.32 \mathrm{mmol})$ in $\mathrm{CH}_{2} \mathrm{Cl}_{2}(5.0 \mathrm{ml})$ and the resulting mixture was stirred for $5-9 \mathrm{~h}$ under argon at $20^{\circ} \mathrm{C}$. The reaction mixture was poured into water $(20 \mathrm{ml})$ and extracted with $\mathrm{CH}_{2} \mathrm{Cl}_{2}(2 \times 5 \mathrm{ml})$. The organic solution was dried over $\mathrm{Na}_{2} \mathrm{SO}_{4}$ and evaporated in vacuo. Purification of the residue by silica gel (L 0.040-0.080 mesh) column chromatography, eluent $\mathrm{CH}_{2} \mathrm{Cl}_{2}-$ hexane $(1: 1 \mathrm{v} / \mathrm{v})$ afforded target compounds 5-7.

5-[4-(o-Carboran-9'-yl) sulfonamidophenyl]-10,15,20triphenylporphyrin (5). Yield $35 \mathrm{mg}$ (70\%). $\mathrm{m} / \mathrm{z}$ (MALDI): 836 $[\mathrm{M}+\mathrm{H}]^{+}$. IR $(\mathrm{KBr}) v_{\max } \mathrm{cm}^{-1}: 3318(\mathrm{NH}), 3058$ (carborane $\mathrm{CH}$ ), $2606(\mathrm{BH}), 1337\left(\mathrm{SO}_{2}\right), 1156\left(\mathrm{SO}_{2}\right)$. UV-Vis $\left(\mathrm{CHCl}_{3}\right) \lambda_{\max }(\lg \varepsilon)$ nm: 420 (4.83), 515 (4.11), 554 (3.88), 593 (3.66), 651 (3.78). ${ }^{1} \mathrm{H}$ NMR $\left(\mathrm{CDCl}_{3}\right) \delta_{\mathrm{H}}$ ppm: $-2.77(2 \mathrm{H}$, br. s, pyrrole $\mathrm{NH}), 2.97(2 \mathrm{H}, \mathrm{s}$, carborane $\mathrm{CH}), 7.79(11 \mathrm{H}, \mathrm{m}, \mathrm{Ph}), 8.24(8 \mathrm{H}, \mathrm{m}, \mathrm{Ph}), 8.63(1 \mathrm{H}, \mathrm{s}$, $\left.\mathrm{NHSO}_{2}\right), 8.87(6 \mathrm{H}, \mathrm{s}, \beta-\mathrm{H}), 8.99(2 \mathrm{H}, \mathrm{s}, \beta-\mathrm{H}) .{ }^{11} \mathrm{~B} \mathrm{NMR}\left(\mathrm{CDCl}_{3}\right)$ $\delta_{\mathrm{B}}$ ppm: $5.5(1 \mathrm{~B}, \mathrm{~s}),-2.5(1 \mathrm{~B}, \mathrm{~d}, J=158 \mathrm{~Hz}),-2.6(2 \mathrm{~B}, \mathrm{~d}, J=156 \mathrm{~Hz})$, -14.5 (4B, d, $J=154 \mathrm{~Hz}),-15.6(2 \mathrm{~B}, \mathrm{~d}, J=166 \mathrm{~Hz})$.

5-[4-(m-Carboran-9'-yl) sulfonamidophenyl]-10,15,20triphenylporphyrin (6). Yield $43 \mathrm{mg}$ (86 \%). $\mathrm{m} / \mathrm{z}$ (MALDI): 835 $[\mathrm{M}]^{+}$. IR (KBr) $v_{\max } \mathrm{cm}^{-1}: 3319(\mathrm{NH}), 3053$ (carborane $\left.\mathrm{CH}\right), 2606$ (BH), $1350\left(\mathrm{SO}_{2}\right), 1157\left(\mathrm{SO}_{2}\right)$. UV-Vis $\left(\mathrm{CHCl}_{3}\right) \lambda_{\text {max }}(\lg \varepsilon) \mathrm{nm}: 420$ (4.52), 517 (4.49), 553 (4.22), 592 (4.03), 651 (4.11). ${ }^{1} \mathrm{H} \mathrm{NMR}\left(\mathrm{CDCl}_{3}\right)$ $\delta_{\mathrm{H}}$ ppm: $-2.68(2 \mathrm{H}$, br. s, pyrrole $\mathrm{NH}), 3.14(2 \mathrm{H}, \mathrm{s}$, carborane $\mathrm{CH})$, 7.57 (9H, m, Ph), 7.93 (2H, m, Ph), 8.29 (8H, m, Ph), $8.64(1 \mathrm{H}, \mathrm{s}$, $\left.\mathrm{NHSO}_{2}\right), 8.88(6 \mathrm{H}, \mathrm{s}, \beta-\mathrm{H}), 8.97(2 \mathrm{H}, \mathrm{s}, \beta-\mathrm{H}) .{ }^{11} \mathrm{~B} \mathrm{NMR}\left(\mathrm{CDCl}_{3}\right) \delta_{\mathrm{B}}$ ppm: -0.9 (1B, s), -6.2 (2B, d, $J=142 \mathrm{~Hz}),-9.6(2 \mathrm{~B}, \mathrm{~d}, J=148 \mathrm{~Hz})$, -13.6 (4B, d, $J=161 \mathrm{~Hz}),-17.2(1 \mathrm{~B}, \mathrm{~d}, J=179 \mathrm{~Hz})$.

5-[4-(o-Carboran-1'-yl) sulfonamidophenyl]-10,15,20triphenylporphyrin (7). Yield $30 \mathrm{mg}(60 \%) . \mathrm{m} / \mathrm{z}$ (MALDI): 835 $[\mathrm{M}]^{+}$. IR (KBr) $v_{\max } \mathrm{cm}^{-1}: 3314(\mathrm{NH}), 3053$ (carborane $\left.\mathrm{CH}\right), 2596$ (BH), $1348\left(\mathrm{SO}_{2}\right), 1155\left(\mathrm{SO}_{2}\right)$. UV-Vis $\left(\mathrm{CHCl}_{3}\right) \lambda_{\max }(\lg \varepsilon) \mathrm{nm}:$ 420 (4.62), 515 (4.43), 553 (3.94), 593 (3.73), 651 (3.82). ' ${ }^{1} \mathrm{H}$ NMR $\left(\mathrm{CDCl}_{3}\right) \delta_{\mathrm{H}}$ ppm: $-2.71(2 \mathrm{H}$, br. s, pyrrole $\mathrm{NH}), 3.98(1 \mathrm{H}, \mathrm{s}$, carborane $\mathrm{CH}), 7.76(11 \mathrm{H}, \mathrm{m}, \mathrm{Ph}), 8.21(8 \mathrm{H}, \mathrm{m}, \mathrm{Ph}), 8.68\left(1 \mathrm{H}, \mathrm{s}, \mathrm{NHSO}_{2}\right)$, $8.87(6 \mathrm{H}, \mathrm{s}, \beta-\mathrm{H}), 8.96(2 \mathrm{H}, \mathrm{s}, \beta-\mathrm{H}) .{ }^{11} \mathrm{~B} \mathrm{NMR}\left(\mathrm{CDCl}_{3}\right) \delta_{\mathrm{B}} \mathrm{ppm}:-1.6$ (1B, d, $J=153 \mathrm{~Hz}),-5.1$ (2B, d, $J=148 \mathrm{~Hz}),-8.9$ (3B, d, $J=147 \mathrm{~Hz})$, -12.5 (3B, d, $J=167 \mathrm{~Hz}),-13.6$ (1B, d, $J=171 \mathrm{~Hz}$ ).

General procedure of synthesis of carboranylporphyrins 11 , 12. To a solution of porphyrin 5 or $6(30 \mathrm{mg}, 0.04 \mathrm{mmol})$ in $\mathrm{CHCl}_{3}$ $(10 \mathrm{ml})$ and $\mathrm{MeOH}(4 \mathrm{ml}) \mathrm{Ni}(\mathrm{OAc})_{2} \cdot 4 \mathrm{H}_{2} \mathrm{O}(18 \mathrm{mg}, 0.07 \mathrm{mmol})$ or $\mathrm{Zn}(\mathrm{OAc})_{2} \cdot 2 \mathrm{H}_{2} \mathrm{O}(16 \mathrm{mg}, 0.07 \mathrm{mmol})$ was added. The resulting mixture was stirred under boiling for 4-6 $\mathrm{h}$ under argon and then was diluted with $\mathrm{CHCl}_{3}(10 \mathrm{ml})$, washed with water $(2 \times 5 \mathrm{ml})$, dried over $\mathrm{Na}_{2} \mathrm{SO}_{4}$, and evaporated to dryness under vacuo. Purification of the residue by column chromatography on $\mathrm{SiO}_{2}$ (eluent $\mathrm{CH}_{2} \mathrm{Cl}_{2}-$ hexane 3:7) afforded target compounds 11, 12.

5-[4-(o-Carboran-9'-yl)sulphonamidophenyl]-10,15,20-tr iphenylporphyrinatonickel(II) (11). Yield $21 \mathrm{mg}$ (59 \%). $\mathrm{m} / \mathrm{z}$ (MALDI): $892[\mathrm{M}+\mathrm{H}]^{+}$. IR (KBr) $v_{\max } \mathrm{cm}^{-1}: 3440(\mathrm{NH}), 3055$ (carborane $\mathrm{CH}), 2615(\mathrm{BH}), 1331\left(\mathrm{SO}_{2}\right), 1139\left(\mathrm{SO}_{2}\right)$. UV-Vis $\left(\mathrm{CHCl}_{3}\right)$ $\lambda_{\max }(\lg \varepsilon) \mathrm{nm}: 417$ (5.37), 530 (4.21). ${ }^{1} \mathrm{H}$ NMR $\left(\mathrm{CDCl}_{3}\right) \delta_{\mathrm{H}}$ ppm: 3.14 $(2 \mathrm{H}$, br. s, carborane $\mathrm{CH}), 7.70(11 \mathrm{H}, \mathrm{m}, \mathrm{Ph}), 7.86(2 \mathrm{H}, \mathrm{d}, \mathrm{Ph} J=7.3$ $\mathrm{Hz}), 7.94$ (2H, d, Ph J=8.3 Hz), 8.01 (m, 4H, Ph), 8.75 (2H, s, $\beta-\mathrm{H})$, $8.94(6 \mathrm{H}, \mathrm{s}, \beta-\mathrm{H}), 9.10\left(1 \mathrm{H}, \mathrm{s}, \mathrm{NHSO}_{2}\right) .{ }^{11} \mathrm{~B} \mathrm{NMR}\left(\mathrm{CDCl}_{3}\right) \delta_{\mathrm{B}} \mathrm{ppm}$ : $5.46(1 \mathrm{~B}, \mathrm{~s}),-2.8(1 \mathrm{~B}, \mathrm{~d}, J=158 \mathrm{~Hz}),-3.0(2 \mathrm{~B}, \mathrm{~d}, J=156 \mathrm{~Hz}),-15.8$ (4B, d, $J=154 \mathrm{~Hz}),-16.6$ (2B, d, $J=166 \mathrm{~Hz})$.

5-[4-(m-Carboran-9'-yl) sulphonamidophenyl]-10,15,20triphenylporphyrinatozinc(II) (12). Yield $28 \mathrm{mg}$ (78 \%). $\mathrm{m} / \mathrm{z}$ (MALDI): 835 [M-Zn] $]^{+}$IR (KBr) $v_{\text {max }} \mathrm{cm}^{-1}: 3423$ (NH), 3060 (carborane $\mathrm{CH}), 2580(\mathrm{BH}), 1337\left(\mathrm{SO}_{2}\right), 1178\left(\mathrm{SO}_{2}\right)$. UV-Vis $\left(\mathrm{CHCl}_{3}\right)$ $\lambda_{\text {max }}$ (lge) nm: 428 (5.28), 566 (3.99), 610 (3.89). ${ }^{1} \mathrm{H} \mathrm{NMR}\left(\mathrm{CDCl}_{3}\right)$ $\delta_{\mathrm{H}}$ ppm: $3.32(2 \mathrm{H}, \mathrm{s}$, carborane $\mathrm{CH}), 7.74(11 \mathrm{H}, \mathrm{m}, \mathrm{Ph}), 8.21(8 \mathrm{H}, \mathrm{m}$, 
$\mathrm{Ph}), 8.56(2 \mathrm{H}, \mathrm{s}, \beta-\mathrm{H}), 8.94$ (6H, br. s, $\beta-\mathrm{H}), 8.82\left(1 \mathrm{H}, \mathrm{s}, \mathrm{NHSO}_{2}\right) .{ }^{11} \mathrm{~B}$ NMR $\left(\mathrm{CDCl}_{3}\right) \delta_{\mathrm{B}} \mathrm{ppm}:-1.8(1 \mathrm{~B}, \mathrm{~s}),-6.3(2 \mathrm{~B}, \mathrm{~d}, J=159 \mathrm{~Hz}),-10.1$ (1B, d, $J=159 \mathrm{~Hz}),-13.2$ (5B, d, $J=168 \mathrm{~Hz}),-16.9$ (1B, d, $J=192 \mathrm{~Hz}$ ).

\section{Results and Discussion}

In the search for new compounds with potential biological activity in the present work we describe a convenient approach to the preparation of new sulfonamide-substituted carboranyl porphyrins 5-7 based on the one-stage reaction of 5-( $p$-aminophenyl)-10,15,20-triphenylporphyrin (1) ${ }^{[30]}$ with 9-mercapto-o-carborane (2), ${ }^{[31]} 9$-mercapto- $m$-carborane (3) ${ }^{[32]}$ and 1-mercapto- $m$-carborane (4). ${ }^{[33]}$ Synthesis of boronated sulfonamide porphyrins 5-7 was carried out through the nucleophilic reaction of an amino group of porphyrin $\mathbf{1}$ with carboranylsulfonyl chlorides $\mathbf{8 - 1 0}$ in the presence of $\mathrm{NaOAc}$ in $\mathrm{CH}_{2} \mathrm{Cl}_{2}$ under argon by simple stirring at room temperature. In compounds $\mathbf{5}, \mathbf{6}$ the porphyrin macrocycle is bound to the boron atom of carborane cluster via the $\mathrm{NHSO}_{2}$ spacer while in compound 7, it is attached to a carbon atom of carborane cluster (Scheme 1). Carboranylsulfonyl chlorides $\mathbf{8 - 1 0}$ were prepared in situ by oxidative chlorination ${ }^{[34]}$ of corresponding mercapto carborane 2-4 with trichloroisocyanuric acid (TCCA) in $\mathrm{MeCN}-\mathrm{H}_{2} \mathrm{O}$ system.

This synthetic approach allowed to obtain the desired sulfonamide porphyrins 5-7 in 60-86 \% yields. It is known that the sulfonyl chlorides can be readily prepared ${ }^{[35]}$ from the corresponding sulfonic/sulfinic acids under the treatment with $\mathrm{SOCl}_{2}, \mathrm{PCl}_{5}$ or $\mathrm{POCl}_{3}$. It should be noted that previous studies of the oxidation of the SH-group of $o$ - and $m$-carboranes with chlorine or bromine resulting in the formation of sulfinic and sulfonic acid derivatives have been reported. ${ }^{[36,37]}$ Compared to these reaction conditions in situ oxidative chlorination of mercapto carboranes is more convenient since it is simple and allows to avoid harsh reaction conditions.

Nickel (11) and zinc (12) complexes of sulfonamide carboranylporphyrins were obtained in 59 and $78 \%$ yields when porphyrins 5 and 6 reacted with $\mathrm{Ni}(\mathrm{OAc})_{2} \cdot 4 \mathrm{H}_{2} \mathrm{O}$ and $\mathrm{Zn}(\mathrm{OAc})_{2} \cdot 2 \mathrm{H}_{2} \mathrm{O}$, respectively, in $\mathrm{CHCl}_{3}-\mathrm{MeOH}$ mixture under argon (Scheme 2).

All synthesized porphyrins 5-7, 11, 12 were isolated by column chromatography (elution with $\mathrm{CH}_{2} \mathrm{Cl}_{2}$-hexane $2: 1,3: 7$, or 1:1) as dark red powders. Structures of porphyrins 5-7, and 11, 12 were established by IR and ${ }^{1} \mathrm{H},{ }^{11} \mathrm{~B},{ }^{11} \mathrm{~B}\left\{{ }^{1} \mathrm{H}\right\}$ NMR spectroscopies and mass spectrometry. IR spectra of all porphyrins contain the intense absorption in the range of 2580-2606 $\mathrm{cm}^{-1}$ attributed to the $\mathrm{BH}$ stretching vibrations. The band at $3060-3053 \mathrm{~cm}^{-1}$ indicated the presence of the carborane $\mathrm{CH}$ groups. Stretching vibrations of the $\mathrm{NH}$ bonds of porphyrins 5-7, and 11-12 are observed in the range of 3423-3319 $\mathrm{cm}^{-1}$. The two IR bands for $\mathrm{SO}_{2}$ group were observed in the range $1350-1337 \mathrm{~cm}^{-1}$ and $1178-1155 \mathrm{~cm}^{-1}$ as expected. ${ }^{1} \mathrm{H}$ NMR spectra of porphyrins 5-7, 11, 12

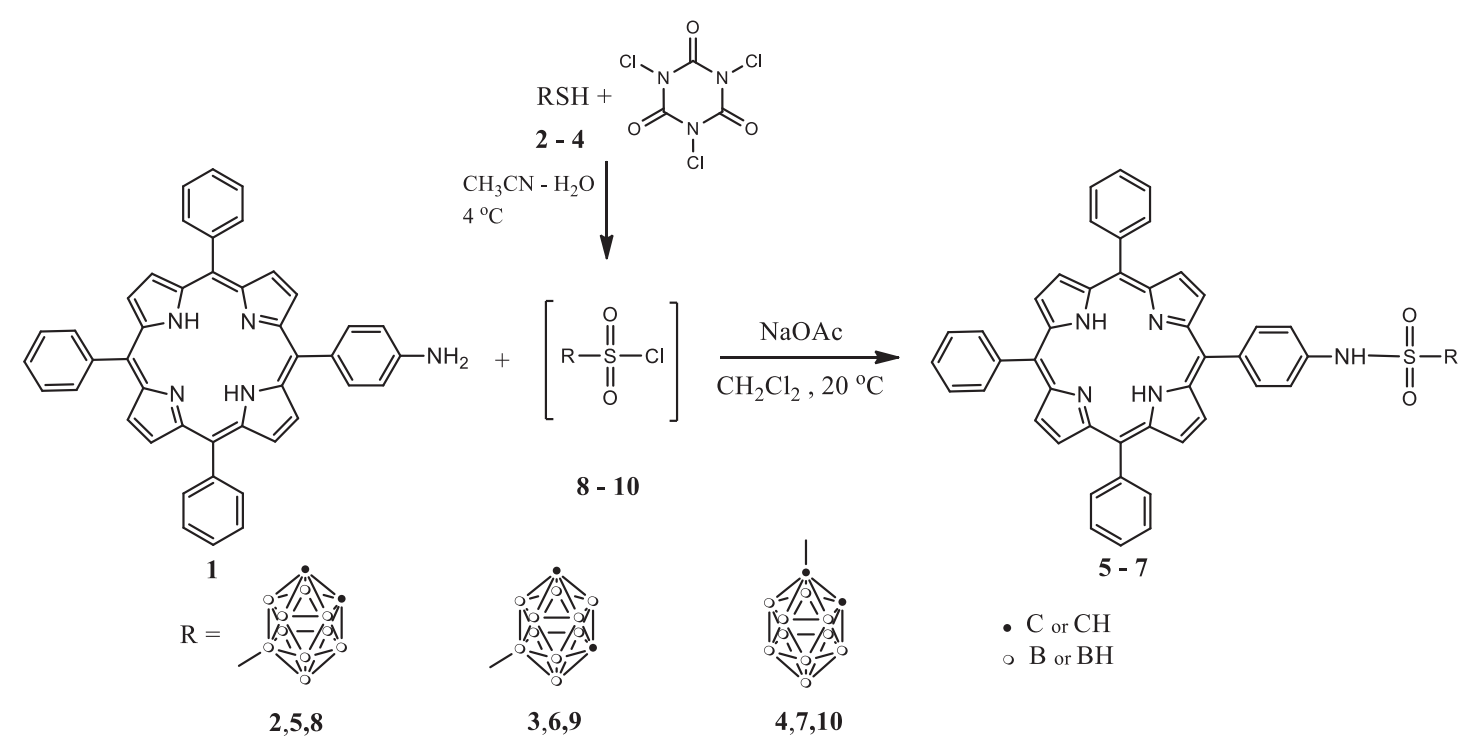

Scheme 1. Synthetic route to the carboranyl substituted sulfonamide porphyrins 5-7.

5

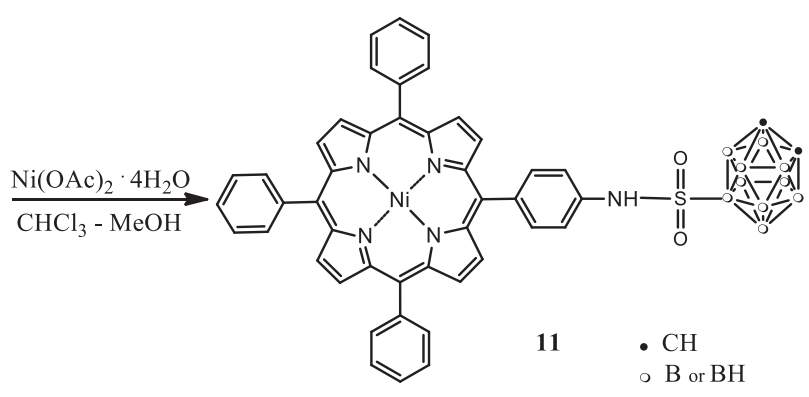

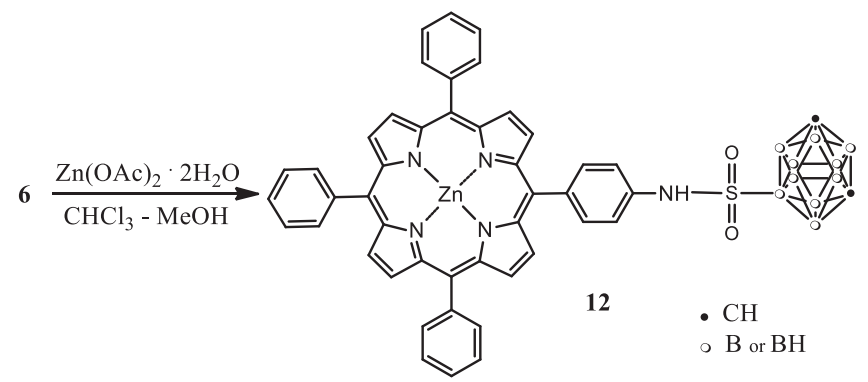

Scheme 2. Synthesis of metal complexes of sulfonamide carboranylporphyrins $\mathbf{1 1}$ and $\mathbf{1 2 .}$ 
exhibit singlet signals of the $\beta$-pyrrole protons at $\delta 8.75-$ $8.99 \mathrm{ppm}$, aromatic multiplet signals at $\delta 7.08-8.29 \mathrm{ppm}$ and broadened singlets at $\delta$ 2.77-(-2.68) ppm associated with two pyrrolic NH-protons in the core of the free base porphyrin for compounds 5-7. Singlet signals at $\delta$ 8.63-9.10 ppm corresponded to the protons of sulfonamide group of prepared compounds. The protons of the carborane $\mathrm{CH}$ groups of $\mathbf{5 - 7}, \mathbf{1 1}, \mathbf{1 2}$ appeared as broad singlets in the interval $\delta 2.97-3.98 \mathrm{ppm}$. It should be noted that signals of all protons in ${ }^{1} \mathrm{H}$ NMR spectra of metallocomplexes 11, 12 shifted downfield relatively corresponding signals in the spectra of free base porphyrins $\mathbf{5}$ and $\mathbf{6}$ that reflects influence of central metal ion on electronic structure both porphyrin and carboran moieties. The ${ }^{11} \mathrm{~B}\left\{{ }^{1} \mathrm{H}\right\} \mathrm{NMR}$ spectra were sufficiently well-resolved to allow integration and contained set of signals between $\delta_{\mathrm{B}} 5.46-(-17.20)$ ppm for compounds 5-7, 11, 12 indicative of the closo-structure of carborane polyhedra.

To predict a number of molecular properties (molecular geometry, total energy, electron structure and dipole moment) quantum-chemical studies were carried out for porphyrins 5-7, 11, 12. Such parameters as geometry optimization, calculation of vibrational mode frequencies, electron density distribution, full energies, transformation energies, transformation entropy were computed at DFT B3LYP/6$31 \mathrm{G}^{*}$ level using GAUSSIAN-09 program suite ${ }^{[38-41]}$ under LINUX. The absence of imaginary frequencies indicates that optimized configurations correspond to the minima on the potential energy hypersurfaces.

The optimized geometries of molecules $\mathbf{5}$ and $\mathbf{1 1}$ in gas phase are given for example in Figures 1 and 2. The structures of $\mathbf{5}$ and $\mathbf{1 1}$ are similar in general. Two phenyl rings situated opposite each other via porphyrin ring (one of them with - $\mathrm{NH}-\mathrm{SO}_{2}$-carboranyl fragment) are located in the same plane which is perpendicular to the plane of porphyrin ring. The planes of other two phenyl rings are crossed at about $70^{\circ}$ to the plane of porphyrin ring (Figure 3). In compound 5 interatomic distance between nitrogen atoms $\mathrm{N}$... $\mathrm{N}$ in porphyrin fragment is 4.078 while in NH...NH it is 4.223 . The insertion of nickel into the porphyrin ring leads to decrease of interatomic distances between nitrogen atoms to 3.876 thus causing the contraction of porphyrin cycle.

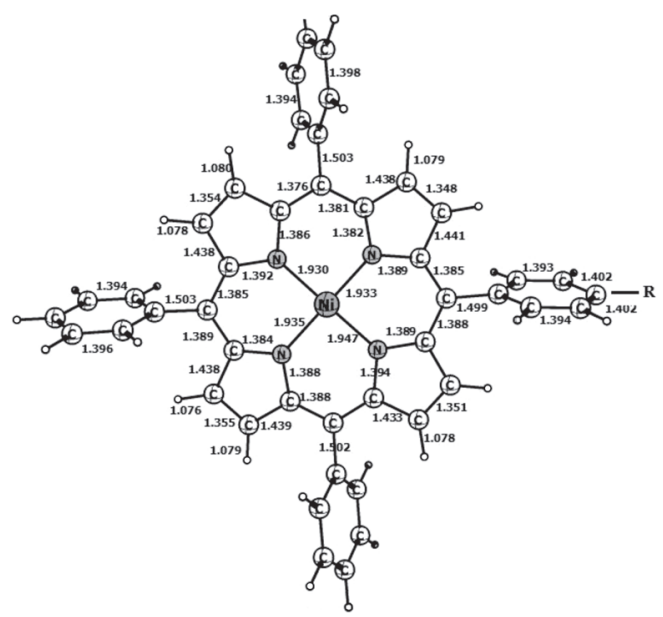

Figure 2. DFT-optimized geometry of porphyrin 11.

Simultaneously, $\mathrm{C}-\mathrm{N}$ distance in triad $\mathrm{CNC}$ increases on $c a$. 0.02 , while $\mathrm{C}-\mathrm{C}$ in triad $\mathrm{CCC}$ diminishes on the same 0.02 . Bond angle (CNC) in $\mathbf{5}$ is $105.4^{\circ}$, while in $\mathbf{1 1}$ it is $103.2^{\circ}$. Table 1 shows the calculated energy characteristics.

The HOMO energy characterizes the electron donating ability and the LUMO energy characterizes the electron accepting ability, while HOMO-LUMO energy gap is very important molecular description to predict stability and reactivity of molecule. Our calculations (Table 2) show that compounds prepared should to be stable both in gas phase and in solution and thus are expected to be successfully used in various applications including antitumor therapy.

The antitumor characteristics of porphyrins $\mathbf{5}$ and $\mathbf{1 2}$ were assessed by measuring the dark toxicity and the ability to cause light-induced death of cultured human tumor cells (HCT116 colon cancer and K562 leukemia cell lines). ${ }^{[42]}$ The porphyrin free base $\mathbf{5}$ which contains the $o$-carborane substituent, exhibited a low dark cytotoxicity against HCT116 line $\left(\mathrm{IC}_{50}>50 \mu \mathrm{M}\right)$, so this compound can be used for PDT. The porphyrin zinc complex 12 exhibited a cytotoxic effect against HCT116 cell line $\left(\mathrm{IC}_{50}=10 \mu \mathrm{M}\right)$ and $\mathrm{K} 562$ $\left(\mathrm{IC}_{50}=5.2 \mu \mathrm{M}\right)$. These agents can be promising as anticancer drug candidates.
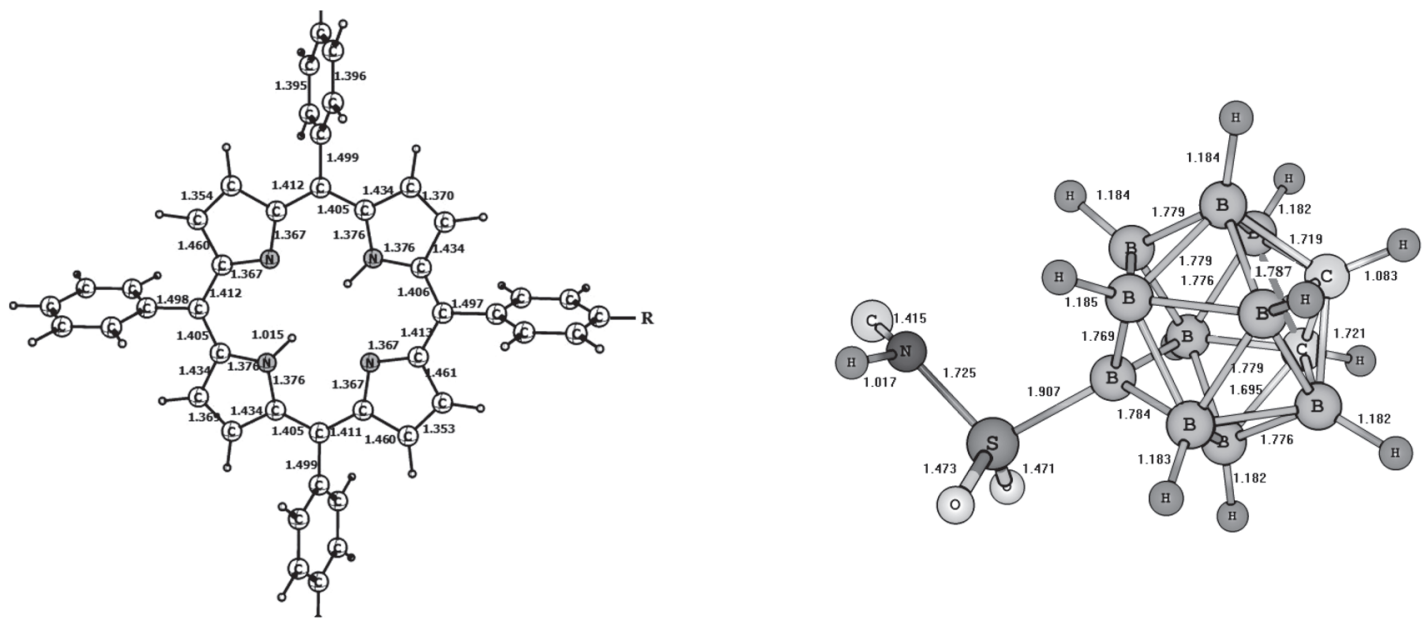

Figure 1. DFT-optimized geometry of porphyrin 5 (left) and carboranyl sulfonamide substituent R (right). 

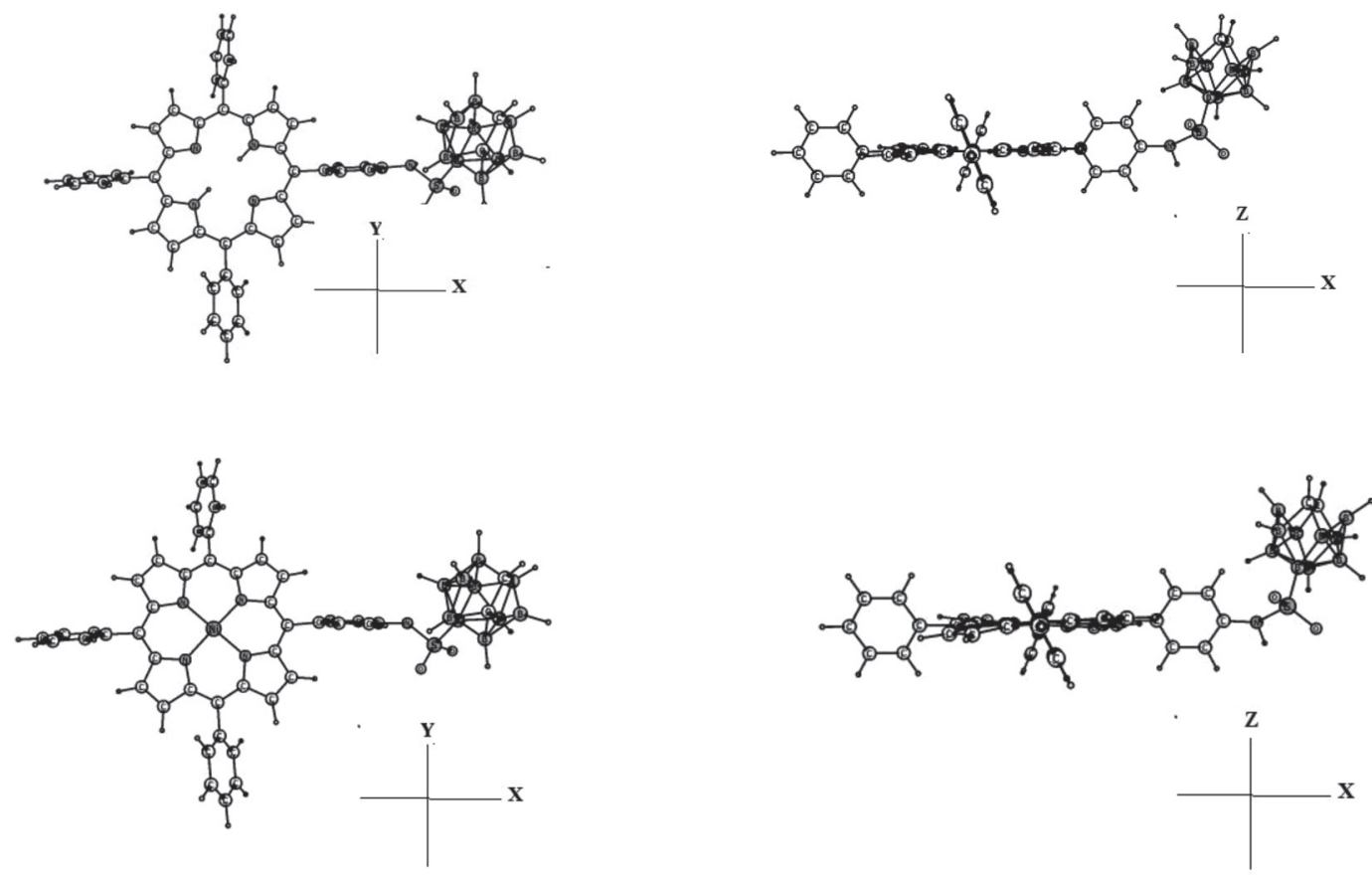

Figure 3. Projections of porphyrin 5 (up) and $\mathbf{1 1}$ (bottom).

Table 1. Computed energy and entropy data for compounds 5-7, 11 and 12 in gas phase and in $\mathrm{CH}_{2} \mathrm{Cl}_{2}$ solution.

\begin{tabular}{ccccc}
\hline Compound & $E_{t}$, a.u. & $E_{z p c}$, a.u. & $E_{G}^{*)}$, a.u. & $S, \mathrm{kcal}^{\circ} \mathrm{M}^{-1} \mathrm{grad}^{-1}$ \\
\hline $\mathbf{5}$ & -2848.5872295 & -2847.782338 & -2847.870512 & 292.078 \\
$\mathbf{6}$ & -2848.6060351 & -2847.800703 & -2847.880995 & 269.489 \\
$\mathbf{7}$ & -2848.5823005 & -2847.778440 & -2847.865545 & 289.206 \\
$\mathbf{1 1}$ & -4355.6506864 & -4354.865832 & -4354.948808 & 276.590 \\
$\mathbf{1 2}$ & -4626.6219318 & -4625.839633 & -4625.929217 & 297.105 \\
$\mathbf{5}+$ solv & -2848.6117504 & -2847.807199 & -2847.894658 & 290.575 \\
$\mathbf{6}+$ solv & -2848.6276585 & -2847.822650 & -2847.903500 & 270.963 \\
$\mathbf{7}+$ solv & -2848.5984504 & -2847.795077 & -2847.882300 & 289.621 \\
$\mathbf{1 1}+$ solv & -4355.6844009 & -4354.900034 & -4354.987936 & 290.537 \\
$\mathbf{1 2}+$ solv & -4626.6526262 & -4625.870595 & -4625.958865 & 294.086 \\
\hline
\end{tabular}

$E_{t}$, - total energy, $E_{z p c}$ - zero point corrected total energy, $\left.E_{G}{ }^{*}\right)-$ Gibbs free energy, computation of $E_{G}$ was carried out at $298.15 \mathrm{~K}, S-$ entropy.

Table 2. Computed dipole moments $(\mu)$, diagonal tensor elements of polarizability $\left(\mathrm{P}_{\mathrm{xx}}, \mathrm{P}_{\mathrm{yy}}, \mathrm{P}_{\mathrm{zz}}\right)$, HOMO and LUMO energies for compounds 5-7, 11 and 12 in gas phase and in $\mathrm{CH}_{2} \mathrm{Cl}_{2}$ solution.

\begin{tabular}{ccccccc}
\hline Compound & $\mu, \mathrm{D}$ & $\mathrm{P}_{\mathrm{xx}}, \mathrm{Bohr}^{3}$ & $\mathrm{P}_{\mathrm{yy}}, \mathrm{Bohr}^{3}$ & $\mathrm{P}_{\mathrm{zz}}, \mathrm{Bohr}^{3}$ & HOMO, a.u. & LUMO, a.u. \\
\hline $\mathbf{5}$ & 7.2988 & 1089.6 & 938.6 & 445.8 & -0.1776 & -0.0785 \\
$\mathbf{6}$ & 6.3076 & 1087.2 & 936.1 & 445.3 & -0.1763 & -0.0794 \\
$\mathbf{7}$ & 3.0082 & 1093.3 & 936.9 & 440.7 & -0.1835 & -0.0841 \\
$\mathbf{1 1}$ & 6.8384 & 1052.0 & 905.6 & 454.6 & -0.1844 & -0.0725 \\
$\mathbf{1 2}$ & 7.3803 & 1081.2 & 933.4 & 453.4 & -0.1800 & -0.0756 \\
$\mathbf{5}+$ solv & 9.5987 & 1413.1 & 1312.9 & 597.3 & -0.1887 & -0.0899 \\
$\mathbf{6}+$ solv & 8.0890 & 1409.7 & 1307.1 & 596.3 & -0.1890 & -0.0900 \\
$\mathbf{7}+$ solv & 3.2480 & 1418.9 & 1312.1 & 590.3 & -0.1903 & -0.0913 \\
$\mathbf{1 1}+$ solv & 9.3466 & 1344.9 & 1263.4 & 623.4 & -0.1941 & -0.0836 \\
$\mathbf{1 2}+$ solv & 9.3891 & 1399.2 & 1307.9 & 607.7 & -0.1876 & -0.0840 \\
\hline
\end{tabular}

$1 \mathrm{Bohr}=0.529177 \mathrm{~A}$ 


\section{Conclusions}

In summary, the one step in situ sulfonamidation of 5-( $p$-aminophenyl)-10,15,20-triphenylporphyrin with mercapto carboranes proposed in this paper is a convenient route to prepare pure and stable boronated sulfonamide porphyrin derivatives in good yields. The minimum energy conformations were subjected to the full range of calculations, including the peripheral phenyl and carborane groups and the solvent. Because of the readily available starting compounds, and reasonable biological characteristics, this synthetic approach might be applicable in material science and medicine.

Acknowledgements. We gratefully acknowledge the contribution of Center for molecule composition studies of INEOS RAS.

\section{References}

1. Bonin J., Chaussemier M., Robert M., Routier M. ChemCatChem 2014, 6, 3200-3207.

2. Kostas I.D., Coutsolelos A.G., Charalambidis G., Skondrab A. Tetrahedron Lett. 2007, 48, 6688-6691.

3. Choi B.G., Ko S.Y., Nam W., Jeong B. Bull. Korean Chem. Soc. 2005, 26, 1819-1822.

4. Senge M.O., Fazekas M., Notaras E.G.A., Blau W.J., Zawadzka M., Locos O.B., Mhuircheartaigh E.M.N. Adv. Mater. 2007, 19, 2737-2774.

5. Smykalla L., Mende C., Fronk M., Siles P.F., Hietschold M., Salvan G., Zahn D.R.T., Schmidt O.G., Rüffer T., Lang H. Beilstein J. Nanotechnol. 2017, 8, 1786-1800.

6. Day N.U., Wamsera C.C., Walter M.G. Polym. Int. 2015, 64 , 833-857.

7. Hasobe T., Sakai H. J. Porphyrins Phthalocyanines 2011, 15, 301-311.

8. Angaridis P.A., Lazarides T., Coutsolelos A.C. Polyhedron 2014, 82, 19-32.

9. Denisov I.G., Makris T.M., Sligar S.G., Schlichting I. Chem. Rev. 2005, 105, 2253-2278.

10. Auwärter W., Écija D., Klappenberger F., Barth J.V. Nat. Chem. 2015, 7, 105-120.

11. Barber J. Chem. Soc. Rev. 2009, 38, 185-196.

12. Pandey R.K., Zheng G. Porphyrins as Photosensitizers in Photodynamic Therapy. In: The Porphyrin Handbook (Kadish K., Smith K.M., Guilard R., Eds.) New York: Academic Press, 2000. p. 157-230.

13. Brown S.B., Brown E.A., Walker I. Lancet Oncol. 2004, 5, 497-508.

14. Renner M.W., Miura M., Easson M.W., Vicente M.G.H. Anticancer Agents Med. Chem. 2006, 6, 145-157.

15. Ol'shevskaya V.A., Zaytsev A.V., Savchenko A.N., Shtil A.A., Cheong C.S., Kalinin V.N. Bull. Korean Chem. Soc. 2007, 28, 1910-1916.

16. Ol'shevskaya V.A., Zaitsev A.V., Dutikova Yu.V., Luzgina V.N., Kononova E.G., Petrovsky P.V., Kalinin V.N. Macroheterocycles 2009, 2, 221-227.
17. Toth J.E., Grindey G.B., Ehlhart W.J., Ray J.E., Boder G.B., Bewley J.R., Klingerman K.K., Gates S.B., Rinzel S.M., Schultz R.M., Weir L.C., Worzalla J.F. J. Med. Chem. 1997, 40, 1018-1025.

18. Badawi A.M., Ali H.E., Ismail D.A. Aust. J. Basic Appl. Sci. 2008, 2, 301-309.

19. Turpin J.A., Song Y., Inman J.K., Huang M., Wallqvist A., Maynard A., Covell D.G., Rice W.G., Appella E. J. Med. Chem. 1999, 42, 67-86.

20. Gupta A.S., Phull M. Indian J. Chem. 1996, 35B, 276-277.

21. Argyropoulou I., Geronikaki A., Vicini P., Zani F. Arkivoc 2009, vi, 89-102.

22. Novotny L., Phillips O.A., Rauko P., Miadokova E. Exp. Oncol. 2006, 28, 293-298.

23. Bhat M.A., Siddiqui N., Khan S.A. Indian J. Pharm. Sci. 2006, 68, 120-124.

24. Casini A., Winum J.-Y., Montero J.-L., Scozzafava A., Supuran C.T. Bioorg. Med. Chem. Lett. 2003, 13, 837-840.

25. Park J.D., Kim D.H., Kim S.-J., Woo J.-R. J. Med. Chem. 2002, 45, 5295-5302.

26. Muraglia E., Kinzel O., Gardelli C., Crescenzi B., Donghi M., Ferrara M., Nizi E., Orvieto F., Pescatore G., Laufer R., Gonzalez-Paz O., Di Marco A., Fiore F., Monteagudo E., Fonsi M., Felock P.J., Rowley M., Summa V. J. Med. Chem. 2008, 51, 861-874.

27. Hulten J., Andersson H.O., Schaal W., Danielson H.U., Classon B., Kvarnstrom I., Karlen A., Unge T., Samulesson B., Hallberg A. J. Med. Chem. 1999, 42, 4054-4061.

28. Manfredi M.C., Bi Y., Nirschl A.A., Sutton J.C., Seethala R., Golla R., Beehler B.C., Sleph P.G., Grover G.J., Ostrowski J., Hamann L.G. Bioorg. Med. Chem. Lett. 2007, 17, 4487-4490.

29. Dow R.L., Paight E.S., Schneider S.R., Hadcock J.R., Hargrove D.M., Martin K.A., Maurer T.S., Mardone N.A., Tess D.A., DaSilva-Jardine P. Bioorg. Med. Chem. Lett. 2004, 14, 3235-3240.

30. Kruper W.J., Chamberlin T.A., Kochanny M. J. Org. Chem. 1989, 54, 2753-2756.

31. Plešek J., Heřmánek S. Collect. Czech. Chem. Commun. 1981, 46, 687-692.

32. Plešek J., Janoušek Z., Heřmánek S. Collect. Czech. Chem. Commun. 1978, 43, 1332-1338.

33. Zakharkin L.I., Zhigareva G.G., Ol'shevskaya V.A., Vinogradova L.E. Zh. Obshch. Khim. 1997, 67, 823-825.

34. Massah A.R., Sayadia S., Ebrahimi S. RSC Adv. 2012, 2, 6606-6616.

35. Rathod C.P., Bhosale P.H., Patil K.G., Rajurkar R.M., Phadtare A.A., Hindole S.S. Indo Am. J. Pharm. Res. 2013, 3, 2795-2807.

36. Semenuk N.S., Papetti S., Schroeder H. Inorg. Chem. 1969, 8, 2441-2444.

37. Zakharkin L.I., Zhigareva G.G. Zh. Obshch. Khim. 1975, 45, 789-798.

38. Parr R.G., Yang Y. Density-Functional Theory of Atoms and Molecules. Oxford: Univ. Press, 1989.

39. Becke A.D. Phys. Rev. 1988, A38, 3098-3100.

40. Lee C., Yang W., Parr R.G. Phys. Rev. 1988, B37, 785-789.

41. Frisch M.J., Trucks G.W., Schlegel H.B., et al. GAUSSIAN 9, Gaussian, Inc., Wallingford, CT, 2009.

42. Sidorova T.A., Nigmatov A.G., Kakpakova E.S., Stavrovskaya A.A., Gerassimova G.K., Shtil A.A., Serebryakov E.P. J. Med. Chem. 2002, 21, 5330-5339. 